\title{
The influences
}

of meteorological

and hydrological factors

on the operation

and performance

of a semi-natural

stormwater reservoir

\section{Andrzej Wałęga (D), Dariusz Młyński (D)}

University of Agriculture in Kraków, Faculty of Environmental Engineering and Land Surveying

Mickiewicza 24/28, 31-059 Kraków, Poland, e-mail: andrzej.walega@urk.edu.pl

\section{Artur Radecki-Pawlik}

Cracow University of Technology, Faculty of Civil Engineering, Warszawska 24, 31-155 Kraków, Poland

\section{DOI: $10.26491 / \mathrm{mhwm} / 111032$}

\footnotetext{
ABSTRACT. The aim of this research was to determine the influences of meteorological and hydrogeological factors on the water level of a rainwater storage and infiltration reservoir. The examined reservoir is located in the urban and industrial area of Krakow, on ground owned by the Polish State Railways (PKP), Kraków-Bieżanów branch. We analyzed a range of climatic (precipitation and evaporation) and hydrological factors (water stage in the reservoir and groundwater level) and their inter-relationships to determine their influences on the water depth regime in the storage and infiltration reservoir. Based on our results, the increase in the water table level in the reservoir is connected with the increase in the groundwater level and it is observed in the spring and summer periods, when meltwater and stormwater enter the reservoir. At the end of July, the groundwater table level increases because of excessive rainfall events. Throughout the entire experimental period, the reservoir was fed by infiltering groundwater from the upper parts of the basin. The water depth averages in the reservoir were closely correlated with the average groundwater table levels, the sum of precipitation from the week prior to the date of the examination of water depth in the reservoir, and the sum of potential evaporation in the given week.
}

KEYWORDS: storm reservoir, heavy rainfall, best management practices, infiltration. 


\section{INTRODUCTION}

In the modern world, human economic activities play an increasingly large role in the changes in hydrological conditions in anthropogenically transformed basins. Thus far, human activity has caused several disruptions to the water circulation and hydrological regime in the context of 24-hour cycles, seasonal cycles, and cycles lasting for many years. The effect of these activities is the number of anthropogenic transformations evident in changes to the retention properties of basins. Most frequently, these changes are multifaceted and difficult to assess objectively as there is no record of the natural, initial conditions (Gutry-Korycka, Ciepielowski 1993). Urbanisation and industrialisation have a particularly adverse effect on the hydrological regime (Byczkowski 1997). Urbanization tends to substitute natural vegetation with impervious surfaces, thus reducing infiltration (Burszta-Adamiak et al. 2019). It also tends to eliminate natural retention ponds and to rectify river courses, thus greatly interfering with superficial flows (O'Driscroll et al. 2010; Wałęga et al. 2015). The natural water cycle, such as rainfall interception, infiltration and evaporation, was unsettled by urbanization, which caused a series of urban flood management issues, e.g. frequent flooding, water environment deterioration and serious water shortages (Tan et al. 2014). When the watertightness of a basin is increased, infiltration and evapotranspiration are limited, leading to a decrease in the groundwater level. In turn, sewage systems, which are adapted to quickly carry away rainwater from the drained basins, may contribute to the rise of flow concentration in receiving bodies of surface water during excessive rainfall events. Huge amounts of rainfall water, which occur during thawing and excessive rainfall events, overload the hydraulics of classic rainfall sewage systems, consequently leading to local damage within the basin area. To prevent such damage, semi-natural devices are increas-

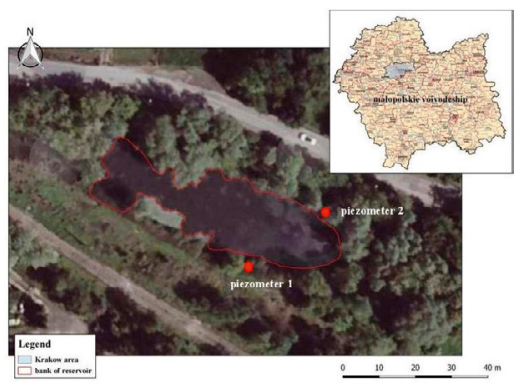

Fig. 1. Location of the storage and infiltration reservoir ingly being used to alleviate problems during excessive rainfall events (Boancă et al. 2018; Wałęga et al. 2018). Such systems are grouped in the category of low-impact development (LID) or best management practices (BMPs) (Ahiablame et al. 2013). The treatment practices have been identified as sustainable methods of managing stormwater, e.g., by temporary retention and subsequent introduction into the ground by infiltration. These solutions are often considered "best management practices" (Fletcher et al. 2015; Wałęga, Wachulec 2018). The "sponge city" is a new concept that can help to increase the protection of a city against storm floods (Dong et al. 2019). This concept is based on green/gray stormwater infrastructure (Li et al. 2018); through different protection and planning strategies for these areas, the integration and connectivity of the ecological sources can be improved, resulting in a higher urban ecological security (Dong et al. 2019). The efficiency of these devices depends on local hydrogeological conditions such as ground permeability, the condition of ground water levels and meteorological conditions, such as precipitation and potential evaporation.

The aim of this research was to determine the influences of meteorological and hydrogeological factors on the changes in water levels in a rainwater storage and infiltration reservoir.

\section{DESCRIPTION OF THE EXAMINED RESERVOIR}

The examined reservoir is located in the urban and industrial area of Krakow (małopolskie voivodeship), on ground owned by the Polish State Railways (PKP), Kraków-Bieżanów branch, on the left side of the railway embankment of the Mydlniki-Gaj route, near the viaduct over the Półłanki St. (Fig. 1).

The location, shape and size of the reservoir are determined by the railway track embankment in the north-west, by Zło- cieniowa St. in the north-east, by Półłanki St. in the north and by uncultivated land covered with bushes and single trees in the south-west. The drained basin mostly has the features of an urbanized basin, which is characterized by the occurrence of impervious surfaces, namely asphalt roads, pavements, rails, railway switches and surfaces under buildings.

The land in the vicinity of the reservoir consists of grasslands, uncultivated grounds covered with bushes and fields for vegetable cultivation. There is no surface water drain in the analyzed area. In the drained area, there are sub-basins with diverse coefficients of surface runoff (Table 1).

The geology of the area, where the storage and infiltration reservoir is located, is the southern edge section of the high fluvial terrace of the Vistula River. Underneath the surface, there is a layer of semi-permeable Holocene and Quaternary Vistula silts with a high content of organic substances and a thickness of a few meters.

There are layers of Pleistocene and fluvioglacial sands and gravel of the glaciation period in the south of Poland, descending to a depth of 10 to $20 \mathrm{~m}$. The stratum for quaternary formations is formed by Neogene, Tertiary, and grabowieckie layers consisting of silts and sands. On the basis of the expert geological opinion issued by BP and RBK in Kraków, it was stated that the water table is at a depth of approximately $2.9 \mathrm{~m}$ below the surface. According to boreholes in the area, down to a depth of $4.5 \mathrm{~m}$, there are sand layers with a filtration coefficient to the value of $k_{f}=8.6 \mathrm{~m} \cdot \mathrm{d}^{-1}\left(9.95 \cdot 10^{-5} \mathrm{~m} \cdot \mathrm{s}^{-1}\right)$. The given filtration coefficient was determined on the basis of the granulometric composition of the ground.

As there is electricity running along the water table, the contractor left a 0.5 -m thick layer (measured from the reservoir bottom) of cohesive soil, with a filtration coefficient of $k_{f}=0.0086 \mathrm{~m} \cdot \mathrm{d}^{-1}\left(9.90 \cdot 10^{-8} \mathrm{~m} \cdot \mathrm{s}^{-1}\right)$ to balance the pressure of the groundwater head. Grain size analysis of the reservoir bed confirmed the previous predictions concerning permeability.

Table 1. The areas of sub-basins the urban and industrial area of Krakow with their corresponding coefficients of surface runoff (Krzanowski, Radecki-Pawlik 1998)

\begin{tabular}{|l|c|c|}
\hline Land cover & $\begin{array}{c}\text { Watershed area } \\
{\left[\mathrm{km}^{2}\right]}\end{array}$ & $\begin{array}{c}\text { Coefficient of surface runoff } \\
{[-]}\end{array}$ \\
\hline Uncultivated ground and vegetable fields & 0.387 & 0.150 \\
\hline Railway areas & 0.058 & 0.300 \\
\hline Roads, car parks, etc. & 0.005 & 0.700 \\
\hline All & 0.450 & $0.175^{*}$ \\
\hline
\end{tabular}

- mean value of surface-runoff coefficient 
In accordance with the modified Pruszyński method, aerometric analysis demonstrated the occurrence of cohesive soil at the bottom of the reservoir, the grain-size distribution of which corresponds with silty clay loams. The granulometric composition of the ground at the bottom of the reservoir is also affected by deposits from excess (unleached) rainwater.

The reservoir complex consists of the following devices for water intake, transport, storage and the treatment of rainwater coming in from the basin:

- Two concrete reduction chambers with sedimentation tanks, located in ditches of the railway viaduct along Półłanki St., with $3 \times 400-\mathrm{mm}$ pipelines connecting the chambers;

- An open channel with a length of $63 \mathrm{~m}$ and a bottom width of $0.4 \mathrm{~m}$, laid at a slope of $2 \%$ and reinforced with prefabricated concrete slabs, taking water from the reduction chambers to the reservoir, secured at the outlet with a rip-rap to absorb the energy of the excess rainwater entering the reservoir;

- A storage and infiltration reservoir with a bottom area of $1,605 \mathrm{~m}^{2}$ and a maximum capacity of $1,951 \mathrm{~m}^{3}$;

- Two piezometers.

The examined reservoir is an earthen structure in the shape of a wedge, narrower at the inlet part (width $B_{1}=15.0 \mathrm{~m}$ ) than the wider section $\left(B_{2}=19.0 \mathrm{~m}\right)$. The length of the reservoir along the side of Złocieniowa St. is $78.8 \mathrm{~m}$, and at the side of the railway embankment, it is $82.5 \mathrm{~m}$. The reservoir bank slope is $1: 1.5$, and the reservoir inlet has a slope of 1:3; its average depth is $1.50 \mathrm{~m}$, and the bottom slope is $2 \%$ in the direction from the inlet towards the reservoir.

To discourage trespassing, the reservoir was fenced. Two piezometers, which were installed at a depth of $1 \mathrm{~m}$ below the level of the groundwater table (the ordinate of the bottom of the piezometer is $197.50 \mathrm{~m}$ above sea level, and the level of filter is about $1 \mathrm{~m}$ ) are used to monitor the quality of the stored unleached rainwater, the fluctuation of the groundwater table, and the purity of groundwater in the immediate vicinity of the reservoir.

\section{RESEARCH}

\section{METHODOLOGY}

As water runoff from the examined reservoir takes place during infiltration to the ground, it was assumed that the water depth regime in the reservoir is determined by the groundwater table level. One of the main functions of the analyzed structure is the storage of water after storms or long periods of rainfall. For this reason, this meteorological factor should significantly affect the water level in the reservoir and the speed at which the reservoir empties. Evaporation from the water surface constitutes another important factor affecting the water depth oscillations in reservoirs with standing water. The evaporation magnitude depends on several factors, such as water vapor pressure, moisture shortage, air temperature, wind speed, as well as the shape and dimension of the reservoir (Jurak 1976; Bac, Rojek 1979; Atlas 1986; Breitschneider et al. 1993; Jaworski 1997). In his sense, the analysis of a range of climatic and hydrological factors and their inter-relationships can help to determine their influences on the water depth regime in the storage and infiltration reservoir.

Water depth in the reservoir was read from the installed water stage rod. The oscillations of the reservoir water depth were observed from September 2003 to November 2004. First, readings were taken once a week, and when the measurements of potential evaporation started (21/05/2004), readings were taken three times a week.

The groundwater table level was measured from January 2003 to November 2004 at piezometers above and below the reservoir, using a hydrogeological whistle. From January 2003 to May 21, 2004, the level of the groundwater table was measured once a week, and subsequently, towards the end of the measuring period, it was measured three times a week.

Precipitation data were obtained from the meteorological station in the village of Koźmice Wielkie near Wieliczka, taken from January 2003 to November 2004. To obtain the full characteristics of the precipitation near the examined reservoir, a Hellmann rain gauge was installed on June 2, 2004. The depth of the precipitation was read from this gauge as the sum of precipitation in the periods between consecutive readings of water depth in the examined reservoir. To obtain the values of the precipitation depth from the period prior to the Hellmann rain gauge installation, a regression equation was calculated, which describes the depth of the precipitation at the meteorological station as a function of the depth of the precipitation from Koźmice:

$$
P_{\text {Biezanów }}=0.726 \cdot P_{\text {Koźmice }}+1.322
$$

The obtained correlation coefficient of the value of 0.616 was statistically significant at the level of $\alpha=0.01\left(r_{o b l}=0.616>r_{k r(55 ; 0.01)}=0.339\right)$.
Potential evaporation was determined via a Piche evaporimeter, which was installed near the reservoir on May 18, 2004, calculated on the basis of values from the periods between the readings from the water stage rod. Air temperature was measured simultaneously with the evaporation rate.

The verification of data used in the model was based on the examination of genetic and statistical homogeneity. In the case of homogeneous data, constant factors affect the process of the given phenomenon (Ozga-Zieliński 1987; Ozga-Zielińska, Brzeziński 1997). As the test results show, the change of the water depth in the reservoir has various origins. In the case of thawing, a slow increase in water depth is observed in the reservoir. However, when short-term rainfall from storms occurs, the reservoir fills up quickly, and the water level gradually falls. A similar situation occurs in the case of variability of the first level of groundwater.

Chełmicki (1991) shows that the water table is mainly fed during the thawing period, whereas in the summer period, despite the occurrence of heavy storms, the level of groundwater does not change significantly. The described relationships show a lack of genetic homogeneity in the case of water depth changeability in storage and infiltration reservoirs and the groundwater table. The remaining variables are determined by constant factors; thus, it can be assumed that the changeability of potential evaporation and the depth of precipitation have the same origin. To confirm these assumptions, a statistical homogeneity test was performed for each independent and dependent variable. The analysis was performed by means of a Kruskal-Wallis rank sum test. In this test, the elements of samples originating from one general population are given ranks; the sum of ranks is then determined, and the importance of the differences of these sums is checked by a $\chi^{2}$ test. The list of the results of statistical homogeneity of variables for which the analysis was performed is shown in Table 2. The performed calculations show that in the case of the water depth in the reservoir and the conditions of the groundwater table, the obtained data are statistically heterogenous. These results confirm that various, changeable-over-time factors affect the course of these phenomena.

Chełmicki (1991), in tests on the regime of the shallow groundwater table in Poland, shows that about $35 \%$ of measuring stations lack statistical homogeneity. The significantly ascending trend of the water table was, most likely, caused by the lack of data homogeneity. 
Heterogenous variables were used in further analyses as they have a decisive influence on the operation of the reservoir. The strong mutual connection between the heterogeneous variables supports their use in further analyses. The interconnections between the selected factors were determined on the basis of the analysis of simple and partial correlations. The importance of the correlation coefficients was established by means of the comparison of their values with the critical values read in the statistical tables at the given significance level $\alpha$ and $\mathrm{n}$ degrees of freedom.

\section{TEST RESULTS}

\section{AND DISCUSSION}

The basic characteristics of the analyzed factors are shown in Table 3, and their variability in the test period is shown in Figures 2a-d.

From the beginning of the tests (13/09/2003) until the end of 2004, the water depth in the reservoir decreased gradually (Fig. 2a), which resulted in the lack of water supply in autumn due to low precipitation. A visible fall in the depth of precipitation in this period was identified (Fig. 2c). Occasional precipitation $(14.5 \mathrm{~mm})$ did not cause any visible changes in the reservoir level. A significant increase in the reservoir water depth was preceded by a larger precipitation in the given period of time and increased air temperature, which then caused thawing and meltwater influx. The maximum influx to the reservoir was recorded on $19 / 04 / 2004$, with a value of $0.78 \mathrm{~m}$ (Table 3, Fig. 2a). A significant rise of the groundwater table, recorded on piezometer 2, also had an influence on the water depth (Fig. 2b).

The spring-summer period was characterized by a gradual, even decrease in reservoir water depth until it reached its minimum value of $0.305 \mathrm{~m}$ on $26 / 07 / 2004$. This decrease resulted from the gradual reduction of rainfall. In this period, the sum of precipitation, calculated for the period between the consecutive readings of water depth in the reservoir, exceeded $20 \mathrm{~mm}$ by six times. The decrease in water depth in the reservoir is connected with the increase in the level of the groundwater table, and consequently, the hydraulic gradient and the efficiency of the infiltration water stream connected with it increased. Another significant increase in reservoir water depth was caused by the 3-day record amount of precipitation from July 28 to 30, 2004, reaching a value of $64 \mathrm{~mm}$ and resulting in an intense run-off feeding of the reservoir, causing a water depth

Table 2. Results of the Kruskal-Wallis test of variable homogeneity

\begin{tabular}{|l|c|c|}
\hline Variables & $\chi^{2}$ value & Analysis results \\
\hline Water depth in the reservoir [m] & 18.831 & Heterogenous \\
\hline $\begin{array}{l}\text { Groundwater table level ground water table } \\
{[\mathrm{m} \text { under the ground level] }}\end{array}$ & 16.179 & Heterogenous \\
\cline { 1 - 2 } Potential evaporation [mm] & 1.417 & Homogeneous \\
\cline { 1 - 2 } Depth of precipitation [mm] & 3.175 & \multirow{2}{*}{ Homogeneous } \\
\hline
\end{tabular}

Table 3. Statistical characteristics of the analyzed variables in the storage and infiltration reservoir in the urban and industrial area of Kraków

\begin{tabular}{|l|c|c|c|c|c|c|}
\hline Variable & Mean $[\mathrm{m}]^{*}$ & $\begin{array}{c}\text { Minimum } \\
{[\mathrm{m}]^{*}}\end{array}$ & $\begin{array}{c}\text { Maximum } \\
{[\mathrm{m}]^{*}}\end{array}$ & $\begin{array}{c}\text { Standard } \\
\text { deviation } \\
{[\mathrm{m}]^{*}}\end{array}$ & $\begin{array}{c}\text { Coefficient } \\
\text { of variation } \\
{[-]}\end{array}$ & $\begin{array}{c}\text { Amplitude } \\
{[\mathrm{m}]^{*}}\end{array}$ \\
\hline Reservoir & 0.385 & 0.140 & 0.780 & 0.193 & 0.501 & 0.640 \\
\hline Piezometer 1 & 1.890 & 0.735 & 2.430 & 0.374 & 0.198 & 1.690 \\
\hline Piezometer 2 & 2.930 & 1.600 & 3.525 & 0.460 & 0.157 & 1.925 \\
\hline $\begin{array}{l}\text { Potential } \\
\text { evapotranspiration }\end{array}$ & 3.820 & 0.060 & 8.100 & 2.354 & 0.616 & 8.040 \\
\hline Precipitation & 8.460 & 0.00 & 64.00 & 11.040 & 1.305 & 64.000 \\
\hline
\end{tabular}

* for potential evapotranspiration and precipitation values are in $\mathrm{mm}$

of $0.525 \mathrm{~m}$ on August 2, 2004. A further increase in water depth was also caused by rainfall, albeit to a lower degree. This is because each consecutive rainfall event fell on saturated ground, and thus, its ability to be absorbed into the ground was limited, which is also proved by the increase in the groundwater table near the reservoir. The second visible maximum fillup of the reservoir to a value of $0.605 \mathrm{~m}$ was recorded on August 9, 2004. After this period, the water depth again decreased to a minimum value of $0.205 \mathrm{~m}$ on October 4, 2004.

The regime of the water table in the reservoir depends on the supply of rainwater and the extent of infiltration. Swelling was caused by thawing run-off during the spring period from March 3 to April 19, 2004, and during extreme rainfall events during summer from July 26 to August 9, 2004. The amplitude of the water depth in the reservoir was $0.64 \mathrm{~m}(0.78-0.14=0.64 \mathrm{~m}$; Table 3$)$. The average water depth in the reservoir during the experimental period was $0.385 \mathrm{~m}$.

After the period of water level increase from the end of March until July 26, 2004, the groundwater table fell to a value of $3.03 \mathrm{~m}$ below ground level. This was a period of sparser precipitation and intense ground evaporation, leading to a decrease in the groundwater table. This decrease was also caused by a reduced supply of water infiltrating from the reservoir to the groundwater table. It is worth noting that the groundwater table rose again in the period from July 26 to August 2, reaching a value of $2.295 \mathrm{~m}$ below ground level. This increase was caused by extreme rainfall events in this period, with a total rain amount of $87.1 \mathrm{~mm}$, accounting for more than $9.8 \%$ of the total rainfall in the experimental period.

After a secondary increase in the groundwater table level recorded by piezometer 2 , a decrease was observed until October 10, 2004, when the level reached $3.21 \mathrm{~m}$ below the ground level. Su sequently, the level has stabilized at $3.209 \mathrm{~m}$ below ground level. The third increase in the groundwater table level was observed from November 9 to 20, 2004, reaching $2.08 \mathrm{~m}$ below the ground level.

The influence of the storage and infiltration reservoir on the groundwater table regime is presented in Figure $3 \mathrm{a}$ and $3 \mathrm{~b}$. The terrain topography impacts the level of the groundwater table, which was measured by piezometer 1, making it higher than the level measured in the reservoir (Fig. 3a). This proves that during the entire experimental period, groundwater infiltrated into the reservoir. The opposite situation occurred below the reservoir (Fig. 3b). Because for most of the experimental period, the level of the water table in the reservoir was higher than the groundwater level, water infiltrated from the reservoir to the groundwater system.

During the entire experimental period, groundwater reached the reservoir only in two cases, on March 24 and 30, 2004 During these times, the groundwater level decreased more rapidly because of water infiltration from thawing and rainfall than the reservoir water level increased. The slower increase of the water level in the reservoir was the result of the slower surface run-off from the basin into the reduction chambers and inlet channel. It must also be stressed that, because the ground layer of the reservoir has 


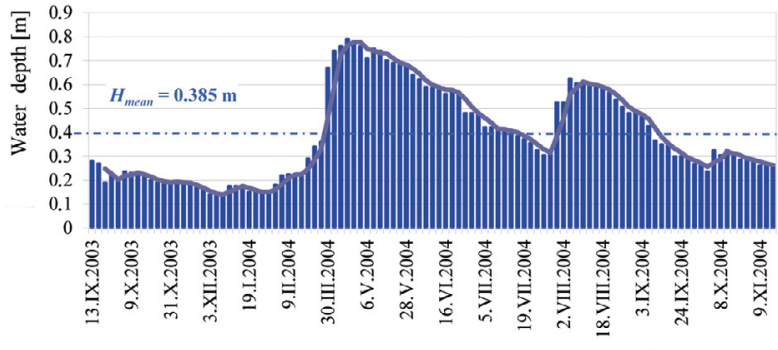

Date of measurement

Fig. 2a. Water depth in the storage and infiltration reservoir in the urban and industrial area of Kraków in the experimental period

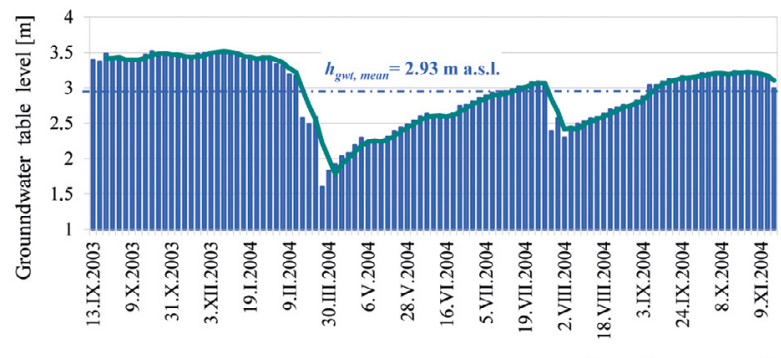

Date of measurement

Fig. 2b. Levels of groundwater table in piezometer 2 in the storage and infiltration reservoir in the urban and industrial area of Kraków

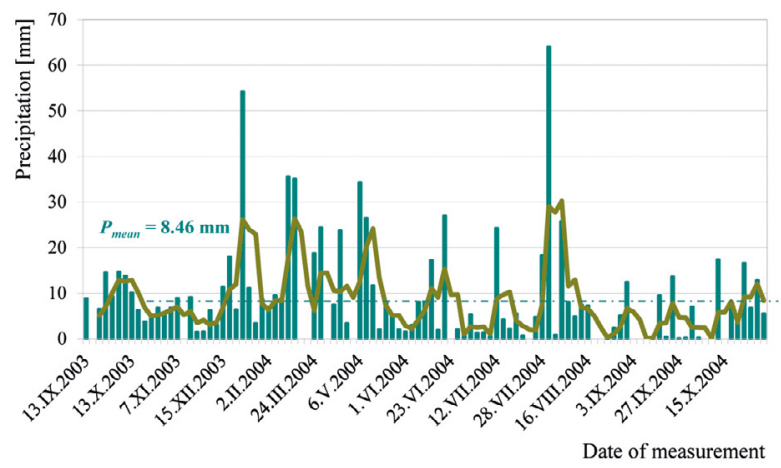

Fig. 2c. Depth of precipitation in the test period in the immediate vicinity of the storage and infiltration reservoir in the urban and industrial area of Kraków reservoir

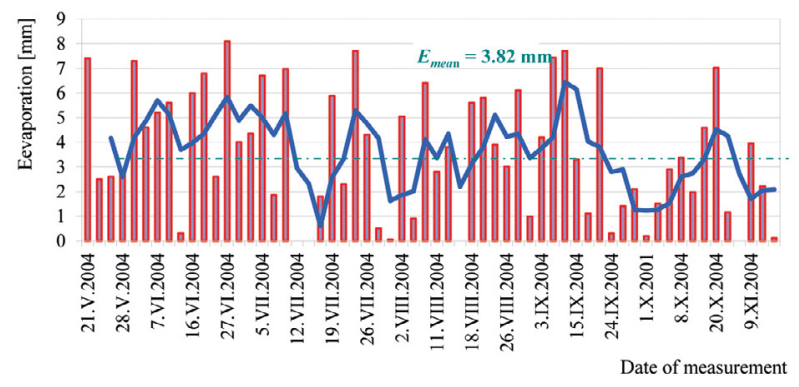

Fig. 2d. Level of the potential evaporation in the examined period in the vicinity of the storage and infiltration reservoir in the urban and industrial area of Kraków; the solid line represents the consecutive mean of three consecutive values
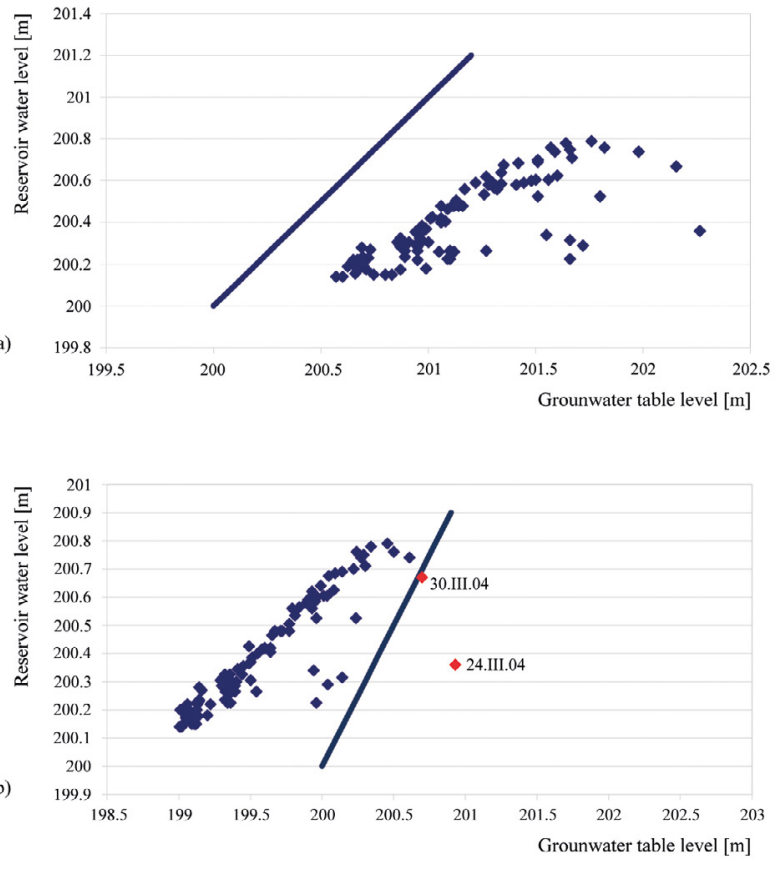

Fig. 3. Relationship between reservoir water level and groundwater table level at piezometer 1 (a) and piezometer 2 (b); the horizontal line represents the situation when the ordinates of the water table in the reservoir are equal to the ordinates of the groundwater table

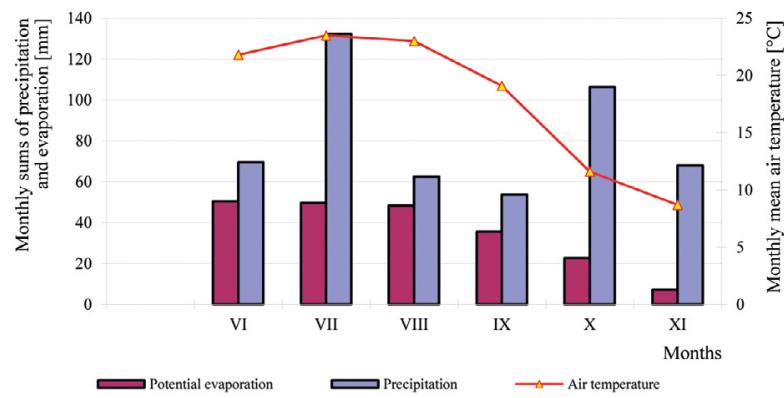

Fig. 4. Monthly sums of potential evaporation and depth of precipitation against the mean monthly air temperature values in close vicinity of the reservoir

Table 4. Matrix of correlation coefficients for the analyzed variables

\begin{tabular}{|l|c|c|c|c|}
\hline Parameter & $H_{\text {res }}$ & $H_{\text {gwt }}$ & $\Sigma P_{i-1}$ & $\Sigma E_{\rho}$ \\
\hline$H_{\text {res }}$ & 1.000 & -0.950 & 0.420 & 0.510 \\
\hline$H_{\text {gwt }}$ & -0.950 & 1.000 & -0.410 & -0.450 \\
\hline$\Sigma P_{i-1}$ & 0.420 & -0.410 & 1.000 & 0.190 \\
\hline$\Sigma E_{\rho}$ & 0.460 & -0.450 & 0.190 & 1.000 \\
\hline
\end{tabular}

$H_{\text {res }}$ - water depth in the reservoir; $h_{\text {owt }}$ - level of groundwater table at piezometer $2 ; \Sigma P_{\text {- }}$ - sum of precipitation from the week before the measurement of water depth in the reservoir; $\Sigma E_{0}$ weekly sum of potential evaporation 
a thickness of around $0.50 \mathrm{~m}$ and a poor permeability (silty clay loams), the levels of the reservoir and the groundwater are related. When the level of the groundwater table is close to the reservoir bed, there is a direct relationship between them, and the groundwater is in direct hydraulic contact with the water in the reservoir; the reservoir is then fed with groundwater. When the level of the groundwater table is below the reservoir bed, these relationships are not direct. The water in the reservoir does not have direct contact with the groundwater, and evaporation from the water surface, evapotranspiration, and precipitation become the more significant factors.

Throughout the entire experimental period from September 13, 2003, to November 20,2004 , the sum of precipitation was $772 \mathrm{~mm}$. Precipitation characteristics of this period were determined on the basis of the classification by Kaczorowska (1962). The depth of normal precipitation in the period from 1850 to 1997 , measured by the weather station at the Botanical Garden of Jagiellonian University in Krakow, was $672 \mathrm{~mm}$ (Twardosz 1999). Taking into account this measurement, the analyzed period in the Krakow-Bieżanów region can be regarded as being wet (with the precipitation sum being $12.9 \%$ higher than the normal precipitation). Twardosz also writes that in the period from 1850 to 1997 , there were 26 wet years.

Potential evaporation fluctuated significantly (Fig. 2d), partly because of the different time spans between successive readings. The maximum sum of evaporation in the experimental period was $8.1 \mathrm{~mm}$, recorded from June 23 to 27, 2004. The highest value of evaporation was $0.06 \mathrm{~mm}$, recorded from July 28 to 30, 2004. (Table 3). Mean evaporation throughout the experimental period was $3.81 \mathrm{~mm}$, with an evaporation sum of $229.2 \mathrm{~mm}$.

In the entire experimental period, the supply of water from precipitation was higher than water loss from evaporation. This was most obvious in July and October, which had the highest values of precipitation sum (Fig. 4). In July, the sum of precipitation was $132.4 \mathrm{~mm}$, while water loss through evaporation was $49.6 \mathrm{~mm}$. In months with relatively high values of air temperature and lower values of precipitation, the proportions of these two parameters were more equal. Such a situation occurred in August and September; the sum of precipitation in these months was 62.6 and $53.8 \mathrm{~mm}$, re- spectively, with mean temperatures of 23 and $19.1^{\circ} \mathrm{C}$, resulting in evaporation values of 48.3 and $35.5 \mathrm{~mm}$, respectively. The evaporation level was $77 \%$ of the precipitation level in August and 66\% of that in September. By comparison, evaporation was only $37.5 \%$ of the depth of precipitation in July.

The vital issue for a designer or user of a seminatural structure is the ability to forecast its functioning, particularly with regard to its filling. To identify factors that affect the depth in the examined reservoir, linear correlation analysis was used. For the weekly mean depth of the groundwater table measured using piezometer 2 , the independent variables were the sum of precipitation from the week before and the weekly sum of potential evaporation

In the performed analysis, the value of precipitation and the value of depth read from the water stage rod 1 week before were taken into account because of the delayed reaction of the reservoir to the precipitation which resulted from the diverse influence of physiographic parameters, especially the shape and the slope of the basin, the use and the characteristics of precipitation, its intensity, its depth, and its duration [Banasik, Barszcz 2000]. The reduction chambers holding the first waves of the run-off also have an effect on the abovementioned delay.

Based on the analysis of the calculations of the correlation between the dependent variable (reservoir water depth) and the other independent variables (Table 4), these depths are mostly connected with the levels of the groundwater table. The calculated correlation coefficient of the value of $r=-0.95$ is statistically significant at the level $\alpha=0.01$ for $N=25$ $(r=-0.95>0.487)$. Such a strong relationship can be explained by the decrease of the hydraulic gradient with increasing groundwater table levels, leading to a decreased filtration efficiency. As a consequence, the run-off by means of the infiltration from the reservoir decreases. This may be the result of the difficulties of water from excessive rainfall filtering through the ground, which is already saturated with water, and the base of the reservoir is sealed. For this reason, most of the rainfall water runs into the reservoir, thus filling it up. In the case of smaller values of precipitation sum in autumn-winter and early spring, the reservoir is supplied with water coming mainly from thawing. This causes the filling of the reservoir and the rise of the groundwater table as a result of the filtration of meltwater to the ground. Our analysis showed a statistically significant relationship between the depth of the water in the reservoir and the sum of the precipitation from the week before the measurement of reservoir filling. The calculated correlation coefficient had a value of 0.42 and was statistically valid at the level of $\alpha=0.05$. This significant relationship is caused by the previously described delayed reaction of the reservoir to the surface run-off. When precipitation increases, especially during excessive rainfall events, the filling of the reservoir increases as a consequence of the higher intensity of inflow than run-off via infiltration and evaporation.

A similar situation to that described above occurs when there is a correlation between the water depth in the reservoir and the level of potential evaporation. The values of potential evaporation, which were used in the calculations, were obtained from the period from the end of May to the end of November. The level of evaporation increased, consequently causing a decrease of the water depth in the reservoir, especially in the period from June to August with high air temperatures. However, the calculated correlation coefficient $(0.5)$ between the water depth in the reservoir and the weekly sum of evaporation seems to contradict the previous statement, most likely because the highest levels of evaporation occurred in the period of the most intense precipitation in the summer months. Thus, the higher rainfall increased the reservoir water depth, which did not decrease afterwards due to a relatively small surface and a smaller thermal potential, despite intense evaporation.

\section{CONCLUSIONS}

Our results led to the following conclusions:

1. The lowest water level was observed in the autumn and winter period as a consequence of a lack of rainfall and a lack of snow and ice thawing. The increase of the water table level in the reservoir is connected with the increase of the groundwater level and it is observed in the spring and summer periods, when there is a high supply of meltwater and stormwater. The average water leve in the reservoir was $0.385 \mathrm{~m}$, with an amplitude of $0.64 \mathrm{~m}$.

2. In the period from the beginning of February to the end of March, the groundwater table increases as a consequence of thawing, and the groundwater system is fed by filtrating 
meltwater. A secondary increase in the groundwater table level can be observed at the end of July, caused by excessive rainfall events.

3. Throughout the entire experimental period, the reservoir was fed by infiltering groundwater from the area of the basin located above the reservoir. However, the reverse situation took place in the section located below the reservoir. For most of the experimental period, the water infiltered from the reservoir, and the groundwater level increased. The exception is the period from the end of March, when groundwater infiltrated into the reservoir as a result of the increased feeding of the water-bearing stratum with meltwater and significant rainfall, with an almost empty reservoir after the autumn and winter periods.

4. The weekly water depth averages in the reservoir are closely correlated with all variables analyzed here, namely average levels of groundwater table below the reservoir in the given week, sum of precipitation from the week prior to the date of the examination of water depth in the reservoir, sum of potential evaporation in the given week. However, the water depth in the reservoir is most significantly connected with the level of the groundwater table. Meteorological factors, such as the sum of precipitation and evaporation, have an influence on the statistically valid relationship between the weekly water depth averages in the reservoir and the corresponding levels of the groundwater table. Because the experiments were performed within a relatively short time, with high sums of annual precipitation, the results are valid only for wet years. For dry or normal years, the relationships between water level in reservoir, sum of precipitation and evaporation, and groundwater levels may be slightly different. For example, for example for normal and dry years, infiltration water from the reservoir may be dominant in both piezometers.

5. Knowledge of all factors affecting the performance of semi-natural rainwater purification plants will help to forecast their operation under various meteorological and hydrogeological conditions, thereby supporting the determination of their impacts on adjacent areas.

\section{REFERENCES}

- Bac S., Rojek M., 1979, Meteorologia i klimatologia, Państwowe Wydawnictwo Naukowe, Warszawa, 250 pp.
- Banasik K., Barszcz M., 2000, Czas opóźnienia odpływu wezbraniowego z małej zlewni rolniczej, Przegląd Naukowy Wydziału Inżynierii i Kształtowania Środowiska, 19, 15-24

- Boancă P., Dumitraș A., Luca L., BorsOprişa S., Laczi E., 2018, Analysing bioretention hydraulics and runoff retention through numerical modelling using RECARGA: a case study in a Romanian urban area, Polish Journal of Environmental Studies, 27 (5), 1965-1973, DOI: 10.15244/ pjoes/79271

- Breitschneider H., Lecher K., Schmidt M., 1993, Taschenbuch der Wasserwirtschaft, Verlag Paul Parey, Hamburg, 1022 pp.

- Burszta-Adamiak E., Licznar P., Zaleski J., 2019, Criteria for identifying maximum rainfall determined by the peaks-over-threshold (POT) method under the Polish Atlas of Rainfall Intensities (PANDa) project, Meteorology Hydrology and Water Management, 7 (1), 3-13, DOI: 10.26491/mhwm/93595

- Byczkowski A., 1997, Wpływ urbanizacji na reżim hydrologiczny małych cieków nizinnych, [in:] Przyrodnicze i techniczne problemy ochrony i kształtowania środowiska rolniczego, Wydawnictwo Akademii Rolniczej im. A. Cieszkowskiego, Poznań, 15-22

- Chełmicki W., 1991, Reżim płytkich wód podziemnych w Polsce, Uniwersytet Jagielloński, Kraków, 136 pp.

- Dong R., Zhang X., Li H., 2019, Constructing the ecological security pattern for sponge city: a case study in Zhengzhou, China, Water, 11 (2), 284-301, DOI: 10.3390/w11020284

- Fletcher T.D., Shuster W., Hunt W.F., Ashley R., Butler D., Arthur S., Trowsdale S., Barraud S., Semadeni-Daves A., Bertrand-Krajewski J.-L., Mikkelsen P.S., Rivard G., Uhl M., Dageanis D., Viklander M., 2015, DUS, LID, BMPS, WSUD and more - The evolution and application of terminology surrounding urban drainage, Urban Water Journal, 12 (7), 525-542, DOI: 10.1080/1573062X.2014.916314

- Gutry-Korycka M., Ciepielowski A., 1993, Naturalne i antropogeniczne zmiany obiegu wody, [in:] Przemiany stosunków wodnych w Polsce w wyniku procesów naturalnych i antropogenicznych, I. Dynowska (ed.), Uniwersytet Jagielloński, Kraków, 271-389

- Jaworski J., 1997., Parowanie terenowe, [in:] Hydrologia dynamiczna, U. Soczyńska (ed.), Wydawnictwo Naukowe PWN, Warszawa, 139-184

- Jurak D., 1976, Intensywność parowania z powierzchni wody w zależności od charakterystyk zbiornika wodnego, Prace IMGW, 10, 5-73

- Kaczorowska Z., 1962, Opady w Polsce w przekroju wieloletnim, Prace Geograficzne, 33, 112 pp.

- Krzanowski S., Radecki-Pawlik A., 1998, Studium nad zagospodarowaniem wód opadowych z deszczy nawalnych w rejonie wiaduktu kolejowego na ciągu ulicy Półłanki w Krakowie-Bieżanowie, Kraków, typescript

- Li X., Fang X., Gong Y., Li J., Wang J., Chen G., Li M.-H., 2018, Evaluating the road-bioretention strip system from a hydraulic perspective - case studies, Water, 10 (12), 1778-1803, DOI: 10.3390/w10121778

- O’Driscoll M., Clinton S., Jefferson A., Manda A., McMillan S., 2010, Urbanization effects on watershed hydrology and in-stream processes in the Southern United States, Water, 2 (3), 605-648, DOI: 10.3390/w2030605

- Ozga-Zielińska M., Brzeziński J., 1997, Hydrologia stosowana, Wydawnictwo Naukowe PWN, Warszawa, $323 \mathrm{pp}$.

- Ozga-Zieliński B., 1987, Badanie statystycznej niejednorodności ciągów pomiarowych, Gospodarka Wodna, 10, 226-228

- Stachy J. (ed.), 1988, Atlas hydrologiczny Polski, IMGW, Warszawa

- Tan P.Y., Abdul Hamid A.R., 2014, Urban ecological research in Singapore and its relevance to the advancement of urban ecology and sustainability, Landscape and Urban Planning, 125, 271-289, DOI: 10.1016/j.landurbplan.2014.01.019

- Twardosz R., 1999, Precipitation variability and tendency in Kraków for the period 18501997 related to circulation patterns, Acta Geophysica Polonica, 47 (1), 111-133

- Wałęga A., Cebulska M., Gądek W., 2018, The use of bioretention cell to decreasing outflow from parking lot, Journal of Water and Land Development, 36 (1-3), 173-181, DOI: 10.2478/jwld-2018-0017

- Wałęga A., Kaczor G., Stęplewski B., 2016, The role of local precipitation models in designing rainwater drainage systems in urban areas: a case study in Krakow, Poland, Polish Journal of Environmental Studies, 25 (5), 2139-2149, DOI: 10.15244/pjoes/62961

- Wałęga A., Wachulec K., 2018, Effect of a retention basin on removing pollutants from stormwater: a case study in Poland, Polish Journal of Environmental Studies, 27 (4), 1795-1803, DOI: 10.15244/pjoes/76797 


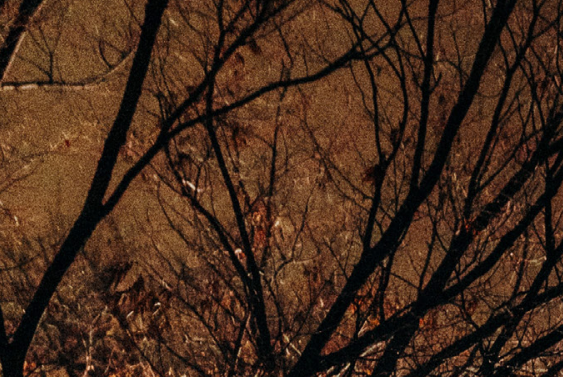

i.

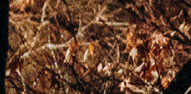

2.t.

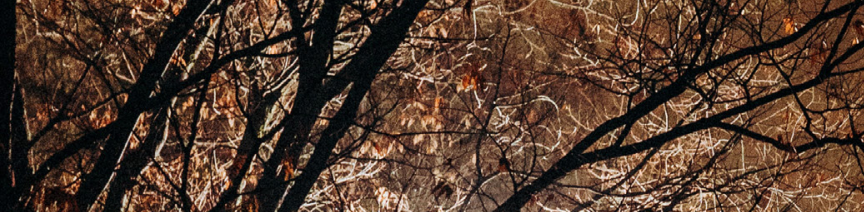

$1 / 4)$

(1)

(I)

C.

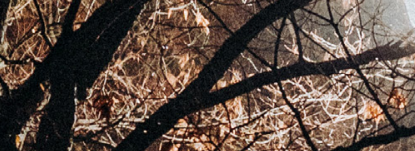

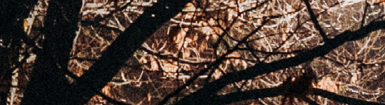

(ivan

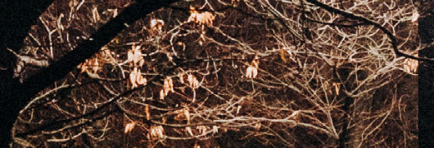

(1) in $x^{2}=\sqrt{1}$

(2)

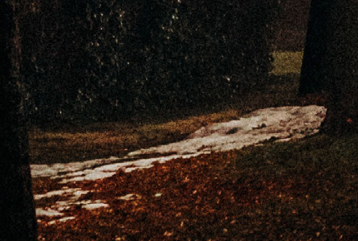

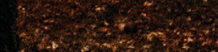

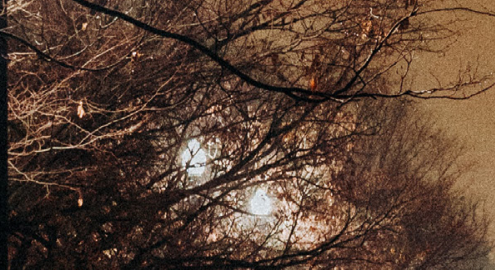

$(2,1)$

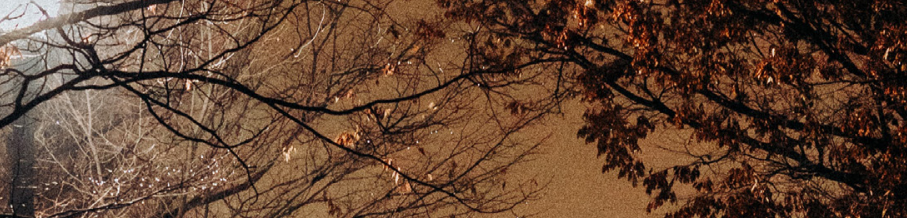

24.

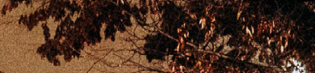

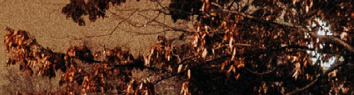

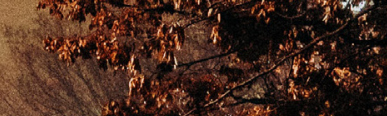

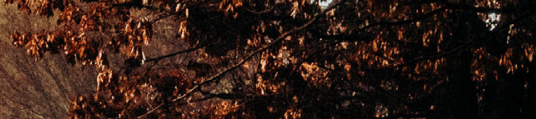

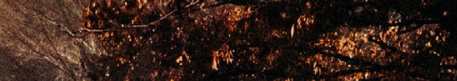

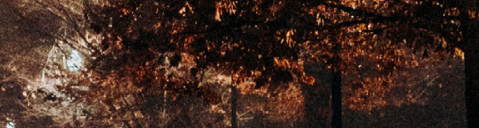

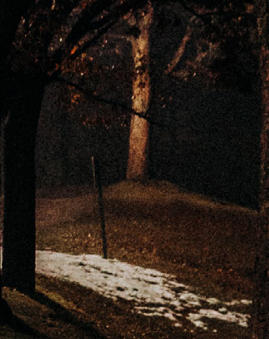

(2)

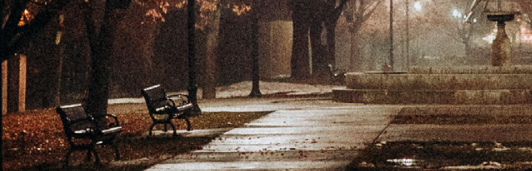

$-2+110$
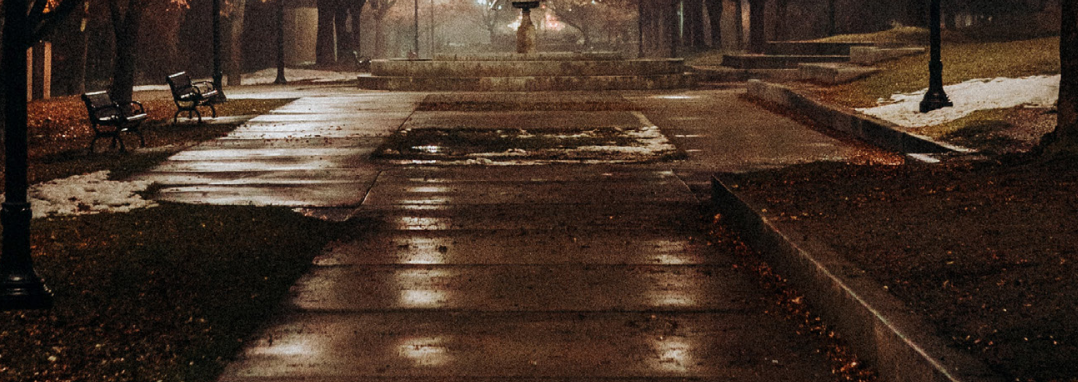

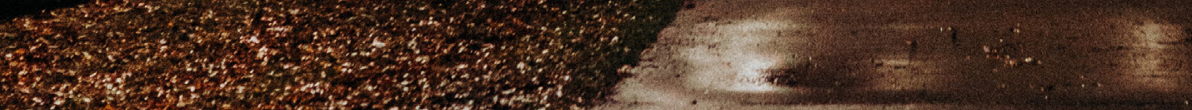

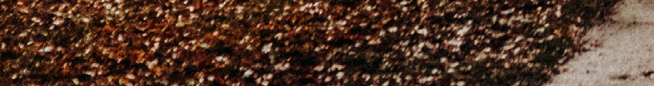

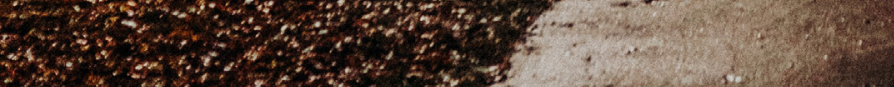

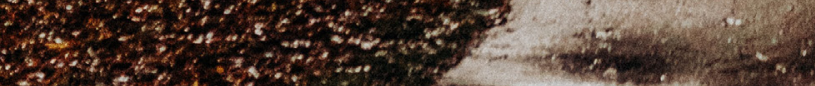

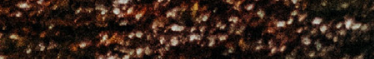

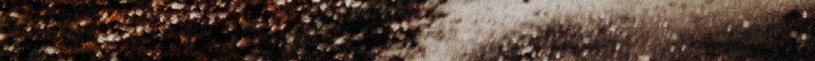

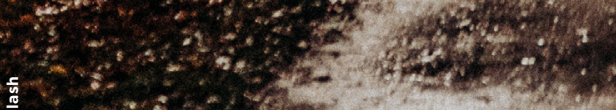

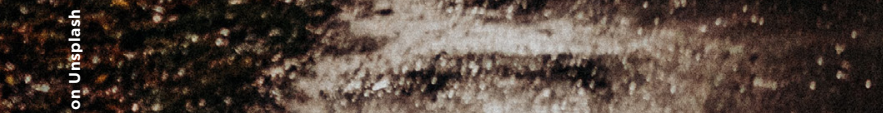

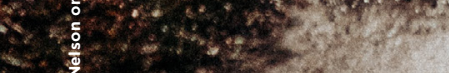

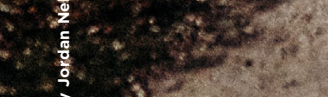

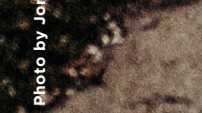

$4^{2}-2.20$

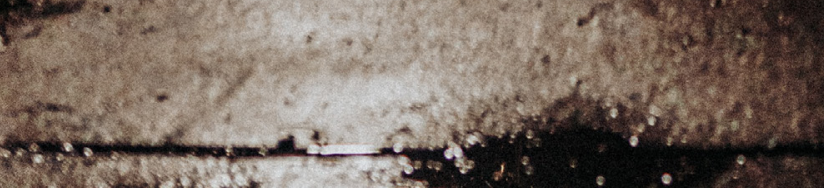

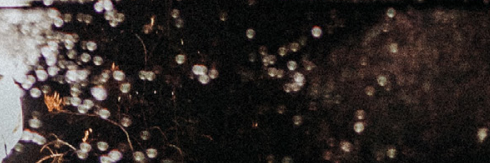

